\title{
Yöneticilerde Yeni Liderlik Becerileri ile Stres İlişkisi: KOMB (VUCA) ve Öz Yeterlilik Etkileşimi*
}

\section{Relationship Between New Leadership Skills and Stress in Managers: KOMB (VUCA) and Self Efficacy Interaction}

\author{
Engin Yurdasever ${ }^{\mathrm{a}, * *}$, Yahya Fidan ${ }^{\mathrm{b}}$ \\ ${ }^{a}$ Öğr. Gör. Dr., Ordu Üniversitesi, Sosyal Bilimler MYO, Ordu/Türkiye. \\ ORCID: 0000-0002-3853-2032 \\ ${ }^{\mathrm{b}}$ Prof. Dr., İstanbul Ticaret Üniversitesi, İşletme Fakültesi, İstanbul/Türkiye. \\ ORCID: 0000-0002-5012-3629
}

\section{MAKALE BILGISİ}

Makale Geçmişi:

Başvuru tarihi: 31 Mart 2020

Düzeltme tarihi: 19 Ağustos 2020

Kabul tarihi: 26 Ağustos 2020

\section{Anahtar Kelimeler:}

Yeni Liderlik Becerileri

Stres

VUCA

KOMB

Öz Yeterlilik
ÖZ

$\mathrm{Bu}$ araştırmada, yöneticilerin sahip oldukları yeni liderlik becerilerinin iş ortamlarında yaşadıkları stres üzerindeki etkisi incelenmiştir. Ayrıca söz konusu liderlik becerileri ile iş ortamında algıladıkları karmaşık, oynak, muğlak ve belirsiz durum ve koşullar ile öz yeterlilik düzeyleri arasında bir etkileşim kurulduğunda, yaşadıkları stresin ne oranda değiştiği de incelenmiştir. Bu amaçla İSO500 - 2016 listesine girmiş kuruluşlarda çalışan 794 orta ve üst düzey yöneticiden eposta yoluyla elde edilen anket verileri ışığında, araştırma değişkenleri arasındaki ilişkiler analiz edilmiştir. Yapısal eşitlik modeli kurularak hipotezlerin test edilmesi sonucunda, yöneticilerin sahip oldukları yeni liderlik becerilerinin yaşadıkları stresi negatif yönlü anlamlı bir şekilde etkilediği gözlenmiştir. Yeni liderlik becerileri ile KOMB ve öz yeterlilik değişkenlerinin etkileşimi ise stres üzerinde anlamlı bir etki ortaya çıkarmamıştır.

\section{ART ICLE INFO}

\section{Article history:}

Received 31 March 2020

Received in revised form 19 August 2020

Accepted 26 August 2020

\section{Keywords:}

New Leadership Skills

Stress

VUCA

KOMB

Self Efficacy

\section{A B S T R A C T}

In this research, the effect of the new leadership skills of managers on the stress in their work environment is examined. In addition, when the interaction between these leadership skills and perceived VUCA and self-sufficiency levels is established, the extent of the stress they experience is examined. For this purpose, with the survey data obtained from 794 middle and senior managers, the relations between research variables were analyzed. As a result of testing hypotheses by establishing a structural equation model, it was observed that the new leadership skills of managers have a negative significant effect on their stress. Interaction of new leadership skills with VUCA and self-efficacy variables did not have a significant effect on stress.

\section{Giris}

Günümüzde birçok yönetici, geçmişten çok farklı olarak, karmaşık, oynak, muğlak ve belirsiz bir iş ortamında çalışmaktadır. Batı'da bu tür iş ortamları VUCA (volatility, uncertainty, complexity, ambiguity) kısaltması ile tarif edilmektedir (Casey, 2014:75). VUCA'yı oluşturan her bir kavram tek başına bozucu etkiye sahip olmasa da

\footnotetext{
* Bu çalışma, sorumlu yazarın 2019 yılında Karabük Üniversitesi Sosyal Bilimler Enstitüsü İşletme Anabilim Dalı’nda Prof. Dr. Yahya Fidan danışmanlığında savunduğu "Yöneticilerde Yeni Liderlik Becerileri ile Stres İlişkisi: KOMB (VUCA) ve Öz Yeterlilik Etkileşimi" başlıklı doktora tezinden üretilmiştir.

** Sorumlu yazar/Corresponding author

e-posta: enginyurdasever@odu.edu.tr
} 
bileşenlerin aynı anda ortaya çıkması yöneticiler açısından çoğunlukla tehdit olarak algılanmaktadır (Prensky, 2014). Her ne kadar içerisinde bir çok firsat barındırsa da pek çok araştırmacıya göre VUCA yöneticilerin karar alma süreçleri açısından ciddi bir tehdit unsurudur ve yöneticilerin VUCA ile başa çıkabilmek için yeni liderlik becerilerine ihtiyacı vardır (Battey, 2012; Collins \& Hansen, 2011; Johansen, 2010) Günümüzde karmaşıklığın, oynaklığın, muğlaklığın ve belirsizliğin -ki böyle ortamlar bu çalışmada kelimelerin baş harflerinden yararlanılarak KOMB kısaltması ile anılmaktadır- bu denli yaygın ve şiddetli olması, yöneticilerin stres düzeyini de dramatik bir şekilde yükseltmektedir.

Günümüzde stres, endişe, huzursuzluk gibi duygular hayatın ayrılmaz bir parçası haline gelmiştir. Özellikle iş çevrelerinde ortaya çıkan hızlı değişimler ve buna bağlı belirsizlikler, çalışanların her geçen gün daha fazla stres yaşamasına sebep olmaktadır (Paşa, 2007:1). Hiç kuşkusuz bu değişim ve belirsizliklerden en çok etkilenen kesimlerin başında karar alma pozisyonunda bulunan orta ve üst düzey yöneticiler gelmektedir (Tutar, 2000:27). Bu sebeple, günümüzde her yöneticinin, strese yol açan sebepleri ve stresin sonuçlarını bilmesi, stresi önleme veya onu yönetme konusunda yeterliliğe sahip olması gerekmektedir.

$\mathrm{Bu}$ araştırmada yöneticilerin yaşadıkları stresin nedenlerini ortaya çıkarmalarına veya stres düzeyini azaltmalarına yardımcı olmak amaciyla, öncelikle KOMB ortamında gerekli olan yeni liderlik becerilerine sahip olup olmadıkları araştırılmış ardından da bu becerilerin stres düzeylerine etki edip etmediği incelenmiştir. $\mathrm{Bu}$ amaçla hazırlanan anket formu yardımıyla Nisan-Aralık 2018 döneminde, İSO5002016 listesine girmiş kuruluşların orta ve üst düzey yöneticilerinden e-posta yoluyla 794 geçerli veri elde edilmiştir. Elde edilen veriler SPSS ve SmartPLS programlarıyla analiz edilerek, araştırma hipotezleri test edilmiştir.

\section{Literatür Özeti}

KOMB, yaşadığımız çalkantılı zamanları özetleyen daha karmaşık, daha oynak, daha muğlak ve daha belirsiz bir iş dünyasını temsil eden kullanışlı bir kısaltmadır (Automatic Data Processing, 2016). İlk olarak Bennis ve Nanus'un (1985) liderlik teorisinden yararlanarak ABD Ordusu tarafindan kullanılan bu kısaltma ve ifade ettiği ortam, temelde askeri kökenli olsa da bugün iş dünyası tarafindan hem benimsenmekte hem de belirgin derecede kendini hissettirmektedir (Brittain, 2012). KOMB, herkesin karş1 karşıya kaldığı, değişken ve kaotik iş, ekonomik ve fiziksel çevreyi en iyi şekilde tanımlamaktadır (Sullivan, 2012). KOMB'u oluşturan bileşenler aşağıda kısaca açıklanmıştır:

Karmaşıklık; çok yönlü konular ve bilgi miktarının fazlalığı nedeniyle karar verme konusunda kafa karışıklığına sebep olan bir ortamı ifade etmektedir (Shaffer \& Zalewski, 2011). Oynaklık; tür, hız, hacim ve ölçek açısından sürekli artan bir değişimi ve değişimin ortaya çıkardığı türbülansı ifade etmektedir (Michel, 2016). Muğlaklık; neden-sonuç ilişkisinin net olmadığı ve bu sebeple bilgi, durum ve olayların yanlış şekillerde yorumlanabilme riskini ifade etmektedir (Cooke, 2013). Belirsizlik ise; öngörülebilirliğin az olmasını, sürprizlerin ortaya çıkma ihtimalinin yüksek olmasını ve spesifik bilgi eksikliğini ifade etmektedir (Guterman \& King, 2014).

İş çevresi açısından KOMB günümüzde olduğu gibi, radikal liderlik değişikliklerinin yaşandığ liderlik becerilerinin yeterli olmayacağı bir ortamı anlatmaktadır (Anonim, 2011). Günümüzde yöneticiler için, KOMB koşullarına uygun yeni becerilere ihtiyaç duyulmaktadır. ABD'de faaliyet gösteren bir düşünce kuruluşu olan Institute for the Future (Gelecek Enstitüsü)'dan Bob Johansen, üst yöneticilerin gelecekte ihtiyaç duyacağı ve KOMB ortamlarında başarılı olabilmeleri için sahip olmaları gereken on yeni liderlik becerisi belirlemiştir. $\mathrm{Bu}$ beceriler şöyle sıralanmaktadır (Johansen, 2012):

- $\quad$ Sezgisel motivasyon becerisi: Bir şeyler yapmak veya geliştirmek için, iç etkenlerden yararlanabilmeyi ifade etmektedir.

- Netleştirme becerisi: Çelişkiler içinden görebilme ve her şeyi olabildiğince açık hale getirebilmeyi ifade etmektedir.

- Krizden firsat çıkarma becerisi: Ortadan kaldırılamayan ikilem ve çelişkileri, avantajlara ve firsatlara dönüştürebilmeyi ifade etmektedir.

- Simülatif ögrenme becerisi: Küçük ölçekli senaryolara dahil olarak, yeni davranışları deneyerek öğrenebilmeyi ifade etmektedir.

- Dirimsel empati becerisi: Olay ve durumları doğanın bakış açısından görebilme, anlayabilme ve öğrenebilmeyi ifade etmektedir.

- Uzlaştırma becerisi: Kutuplaşmaları ortadan kaldırarak, farklı kültürden insanları olumlu etkileşim içine sokabilmeyi ifade etmektedir.

- Mütevazi şeffaflık becerisi: Önem arz eden işleri, açık, samimi, alçakgönüllü ve özgün olarak yapabilmeyi ifade etmektedir.

- Hızl modelleme becerisi: Yeniliklerin, hızlı bir şekilde ilk uyarlamasını yapabilme ve uygulayabilmeyi ifade etmektedir.

- Sanal takımlar örgütleme becerisi: İnternet aracılığıyla büyük bir grubu ortak bir iş veya sosyal değişim amacı ile bir araya getirebilmeyi ifade etmektedir.

- Pastay büyütme becerisi: Hem rekabeti artıran hem de başkalarına fayda sağlayan, paylaşılan varlıklar oluşturabilmeyi ifade etmektedir.

Johansen'e (2012) göre yöneticilerin KOMB dünyasında etkili bir şekilde liderlik etmek için bu becerilere sahip olması gerekmektedir. Bununla birlikte, KOMB dünyasında ortaya çıkan hızlı değişimler, bu değişimlerin getirdiği belirsizlikler ve pek çok konuda artan karmaşıklık düzeyi yöneticiler için ciddi birer stres kaynağı olarak karşımıza çıkmaktadır. Bunlara ek olarak teknolojik değişim hızı ve benzer dişsal faktörler yöneticilerin bu yeni gelişmelere ayak uydurmasını zorlaştırmakta ve daha yoğun bir şekilde iş kaynaklı stres yaşamalarına sebep olmaktadır (Paşa, 2007:1).

Yöneticilerin iş hayatında yaşadığı en büyük problemlerden biri olan stres kavramının ilk olarak bir fizikçi ve biyolog olan Robert Hooke tarafindan kullanıldığı kabul edilmektedir. Hooke, köprüler gibi fiziksel yapıların üzerine gelen yükleri taşımaları için nasıl tasarlanmaları gerektiği üzerinde çalışırken, “yük” kavramını yapı 
üzerindeki ağırlık, yükün bindiği alanı "stres", yapıdaki yük ve stresin etkisi ile meydana gelen bozulmayı ise "gerilim" olarak tanımlamıştır (Lazarus, 1993:4). Bununla birlikte zaman içinde biyoloji, psikoloji ve yönetim bilimlerinde, stresin insanlar üzerindeki etkisini konu edinen pek çok araştırma yapılmıştır (Örnek \& Aydın, 2008:135). Stresi canlı organizmalar bağlamında ele alan ilk kişi olan Cannon ise stres kavramını, "istenmeyen çevresel etkenlerden dolayı bozulan fizyolojik iç dengeyi yeniden kazanmak için gerekli olan fizyolojik uyaranlardır" şeklinde tanımlamıştır (Erdoğan, 1999:269). Bu ve benzer tanımlardan da anlaşılacağı üzere strese yol açan en önemli faktör "çevre"dir. $\mathrm{Bu}$ sebeple içinde bulunduğumuz ve çalışmamızda KOMB olarak Türkçe'ye uyarlanan karmaş1k, oynak, muğlak ve belirsiz özellikler gösteren iş çevreleri, yönetici stresi ile yakın ilişki içerisindedir.

Bireylerde strese yol açan bir diğer faktör ise "bireyin kendisi”dir (Eren, 2004: 293). Bir başka ifade ile, insanların yaşadıkları stresin ortaya çıkışı, bizzat kendi bireysel niteliklerine bağlı da olabilmektedir. Kişiliği oluşturan karakter, mizaç, huy ve yetenekler bireylerde strese yol açabilirken aynı zamanda stres düzeylerini azaltıı bir etki de ortaya çıkarabilmektedir (Tutar, 2000:222). Bireyin kendisi ile ilgili en ölçülebilir özelliklerden birisi ise öz yeterlilik düzeyidir. $\ddot{O} z$ yeterlilik kavramı ilk kez 1977 yılında ünlü psikolog Albert Bandura tarafindan ileri sürülmüştür. Bandura'ya (1982) göre öz yeterlilik, bireyin karşılaşabileceği olay, durum veya koşullar karşısında nasıl bir davranış sergileyeceğine ilişkin kendisi hakkındaki yargısıdır. Araştırmalar, güçlü öz yeterlilik inancına sahip bireylerin, daha başarılı, daha sağlıklı ve daha az stresli olduğunu göstermektedir (aktaran: Yiğitbaş ve Yetkin, 2003:6). Öz yeterliliği yüksek bireyler, strese yol açabilecek herhangi bir zorlukla karşılaştıklarında, ondan kaçmak yerine onun üstüne giderek mücadele etme yolunu seçerler (Hazır Bıkmaz, 2004). Kısaca daha az stres yaşar ve stresin yol açabileceği olumsuzluklardan daha az etkilenirler (Akgündüz, 2012:46).

\section{Yöntem}

\subsection{Araştırmanın Amacı ve Önemi}

$\mathrm{Bu}$ araştırmanın temel amacı, yöneticilerin yeni liderlik becerilerine sahip olma düzeyinin, iş ortamında yaşadıkları stres düzeyine etki edip etmediğini ortaya koymaktadır. Bunun yanında araştırmanın ikincil amacı da yöneticilerde yeni liderlik becerilerine sahip olma düzeyinin, KOMB ve öz yeterlilik düzeyleri ile etkileşime girdiğinde yönetici stresi üzerindeki bir etkisinin olup olmadığını incelemektir.

Günümüzün belki de en yaygın sorunların başında stres gelmektedir. Hemen her insan, farkında olsun olmasın yoğun bir stres yaşamaktadır. İnsanların hayatlarının büyük bir bölümünü işyerlerinde ya da işe bağlı faaliyetler ile geçirdikleri düşünüldüğünde, iş ortamında ya da mesleğe bağl1 olarak ortaya çıkan stresin önemi her geçen gün artmaktadır. İşs stresi ya da örgütsel stres olarak ifade edilen bu durum, pek çok örgütsel sorunu da beraberinde getirmektedir. $\mathrm{Bu}$ yüzden örgütlerde strese etki eden faktörleri ve bunların etki düzeylerini ortaya koymak önem arz etmektedir.

\subsection{Araştırmanın Uygulanması}

$\mathrm{Bu}$ araştırmada, araştırmanın amaçları doğrultusunda geliştirilen ve seçilen ölçekler yardımıyla anket formları oluşturulmuş ve katılımcilara e-posta yolu ile uygulanmıştır. Uygulama çalışması, Karabük Üniversitesi Sosyal ve Beşerî Bilimler Araştırmaları Etik Kurulu'nun 31.05.2018 tarih ve 2018/07 sayll toplantısinda alınan 3 numaralı karara istinaden gerçekleştirilmiştir.

Ölçeklerin anket formuna dönüştürülmesi sonucunda, ilk olarak örneklem içerisinden seçilen 50 kişilik bir gruba anket uygulanmış ve elde edilen verilere geçerlilik ve güvenilirlik analizleri yapılmıştır. $\mathrm{Bu}$ analizler sonucunda faktör yükü çok düşük olan ve güvenilirliği düşüren birkaç ifadenin analiz dışı bırakılması ile içeriğinde birden fazla ölçek kullanılan bir anket formu hazırlanmış ve katılımcılara gönüllülü̈k esasına göre uygulanmıştır. Nisan 2018 ile Aralık 2018 dönemleri arasında gerçekleştirilen veri toplama süreci sonunda 794 adet geçerli anket formu elde edilmiştir.

Elde edilen verilerin tanımlayıcı istatistiklerinin hesaplanması, güvenilirlik analizi, normallik analizi ve açıklayıcı faktör analizleri için SPSS 21.0 programı kullanılmıştır. Doğrulayıcı faktör analizi, yapısal eşitlik modelinin kurulması ve hipotez testleri için ise SmartPLS 3.2.8. programı kullanılmıştır. Yine SmartPLS programında yapısal eşitlik modelinin kurulabilmesi için gerekli olan güvenilirlik analizi, birleşme ve ayrışma geçerliliği analizi ve çoklu doğrusal bağlantı analizleri yapılmıştır.

\section{3. Ölçüm Arac1}

Araştırma kapsamında kullanılan ölçekler şunlardır:

Yeni Liderlik Becerileri Ölçeği (YLBÖ), Johansen'in (2012) "Leaders Make The Future" kitabindan yararlanılarak ve bilimsel ölçek geliştirme süreci takip edilerek yazar tarafindan geliştirilmiş ve Türkçe'ye uyarlanmıştır. Yöneticilerin, KOMB dünyasında ihtiyaç duyulan yeni liderlik becerilerine ne düzeyde sahip olduğunu ölçmek için geliştirilen ölçek, tek boyut ve 10 maddeden oluşmaktadır.

Algllanan Stres Ölçeği (ASÖ), Levenstein vd. (1993) tarafindan geliştirilmiş ve yazar tarafindan Türkçe'ye uyarlanmıştır. Kişilerin kendilerini ne derece stresli algıladıklarını ölçmek için geliştirilen ölçek, 7 boyut (rahatsızlık, aşırı yük, asabiyet, keyifsizlik, yorgunluk, endişe, gerginlik) ve 30 maddeden oluşmaktadır.

KOMB Ölçeği (KOMBÖ), kapsamlı literatür taramaları sonucunda, bilimsel ölçek geliştirme süreçleri takip edilerek yazar tarafindan geliştirilmiş ve Türkçe'ye uyarlanmıştır (Yurdasever, 2019:22). Yöneticilerin iş çevrelerini KOMB olarak algılama düzeylerini ölçmek için geliştirilen ölçek, 4 boyut (karmaşıklık, oynaklık, muğlaklık, belirsizlik) ve 20 maddeden oluşmaktadır.

Genel Öz Yeterlilik Ölçeği (GÖYÖ), Schwarzer ve Jerusalem (1995) tarafindan geliştirilip, Aypay (2010) tarafindan Türkçe'ye uyarlanmıştır. Bireylerin yeni ve zor görevlerle başa çıkma yeterliliğine dair inançlarını ölçmeye yarayan ölçek, tek boyuttan ve 10 maddeden oluşmaktadır.

Yukarıda açıklanan tüm ölçeklerde Likert tipinde 5'li derecelendirme kullanılmışırı. Buna göre anketlerdeki değerlendirme aralıkları; "1-Kesinlikle Katılıyorum, 2- 
Katıliyorum, 3-Kararsızım, 4-Katılmıyorum, 5-Kesinlikle Katılmıyorum" olarak belirlenmiştir.

\subsection{Anakütle ve Örneklem}

Araştırmanın evreni, İstanbul Sanayi Odası tarafından hazırlanan İSO500-2016 listesine girmiş, 500 büyük sanayi kuruluşunun orta ve üst düzey yöneticileridir.

Söz konusu işletmelerde tüm yöneticilere ulaşmanın güçlüğü sebebiyle, her işletmeden bir üst düzey yönetici, iki de orta düzey yönetici ile iletişime geçilip araştırmaya katılımları talep edilmiştir. Dolayısıyla araştırma evreni içerisinden 1.500 kişilik rastgele bir örneklem seçimine gidilmiştir. Yapılan görüşmeler ve gönüllülük esasına göre gerçekleşen katılımlar neticesinde, 794 geçerli geri dönüş sağlanmıştır. Ancak örneklem olarak seçilen 1500 kişiye, anket formlarındaki soruların tamamı yöneltilmemiştir. Araştırmada "ortak metod varyansı" sorununun yaşanmaması için 70 sorudan oluşan anket formu ikiye bölünmüş, bağımsız değişkene ait ifadelerin içinde bulunduğu 30 soruluk anket formu (YLBÖ ve KOMBÖ'den oluşmaktadır) birinci 750 kişilik gruba, bağımlı değişkene ait ifadelerin içinde bulunduğu 40 soruluk diğer anket formu (ASÖ ve GÖYÖ'den oluşmaktadır) ise ikinci 750 kişilik gruba uygulanmıştır. Toplamda geri dönüşü sağlanan ve geçerli sayılan 794 anket formunda yer alan ifadeler birleştirilmiş ve araştırma modelinin ve hipotezlerin ölçülebilmesi için 397 nihai veriye ulaşılmıştır. Yapılan hesaplamalara göre, araştırma evrenin büyüklüğü ne olursa olsun, evreni temsil ettiği kabul edilen azami örneklem sayıs1 384'dür (Gürbüz ve Şahin, 2017:130). Bir başka deyişle 384 veriden daha fazla sayıda veri toplanması, örneklemin temsil yeteneğini yani evren hakkındaki yargıyı değiştirmeyecektir. Dolayısıyla bu araştırmada elde edilen veri sayısı (397), sözü edilen sınırın üstünde olduğundan, seçilen örneklemden elde edilen veri sayısının evreni temsil etme açısından yeterli olduğunu söylemek mümkündür.

\subsection{Kapsam ve Sinırliliklar}

Araştırmanın kapsamını, İSO500-2016 listesine girmiş 500 büyük sanayi kuruluşunun orta ve üst düzey yöneticilerinin araştırma değişkenleri hakkındaki görüşleri oluşturmaktadır. $\mathrm{Bu}$ listede yer alan her işletmenin organizasyon yapısı birbirinden farklı olduğundan, evrende yer alan toplam yönetici sayısını söyleyebilmek mümkün değildir. Ancak sayısı ne olursa olsun işletmelerin tüm orta

\footnotetext{
${ }^{1}$ Ortak metod varyansı; kişilerin tutum, davranış, algı ve/veya inanışlarını araștıran ampirik araștırmalarda, tüm verilerin aynı kişilerden, aynı zamanda ve aynı metodla toplanması durumunda ortaya çıkan önemli bir problemdir. Çünkü verilerin bu şekilde toplanması, metod varyansının iki değișken arasındaki gözlenmiş korelasyonunun, olduğundan daha fazla veya daha az (yapay olarak) olması ihtimalini ortaya çıkarmaktadır (Lindell ve Whitney, 2001; Podsakoff vd., 2003; Richardson vd., 2009; Convay ve Lance, 2010; Podsakoff vd., 2012). Bağımlı ve bağımsız değişken arasındaki gözlenmiş ilişsiyi aşırı şekilde arttırabilen ya da azaltabilen bu durum, gerçekte var olan teorik ilişkinin yokmuş gibi ya da olmayan bir ilişkinin varmış gibi kabul edilmesine yol açabilmektedir (Williams vd., 2010; Convay ve Lance, 2010). Ortak metod varyansının ortaya çıkmasına sebep olan ana faktör, bağımlı ve bağımsız değişkenlere ait verinin aynı kaynaktan veya denekten toplanmasıdır (Podsakoff vd., 2003). Bağımlı ve bağımsız değişkenlere ait verinin farklı kaynaklardan (kişilerden) toplanmasının sağladığı en önemli avantaj, kişilerin ortak bir akıl kullanarak gözlenen ilișkilerde bir yanılma (bias) ortaya çıkarmasının mümkün olmamasıdır (Özyılmaz ve Eser, 2013:506).
}

ve üst düzey yöneticilerine ulaşmanın olanaksızlığı, araştırmanın en büyük kısıtını oluşturmaktadır.

Araştırma evreninin belirlenmesinde kullanılan İSO500 listeleri, her yıl değişiklik göstermektedir. Bu araştırmada yalnızca İSO500-2016 listesinde yer alan kuruluşlardan elde edilen verilerin kullanılmış olması, araştırmanın bir diğer kısıtıdır.

Araştırmada kullanılan tüm veriler e-posta yoluyla elde edilmiştir. Anketlerin öz bildirim yöntemiyle doldurtulması, cevapların doğru yönetici tarafindan doldurulup doldurulmadığı ve yine yöneticilerin gerçek düşüncelerini yansıtıp yansıtmadığı konularında riskler taşımaktadır. $\mathrm{Bu}$ da araştırmanın bir başka kısıtıdır.

\subsection{Araştırma Modeli ve Hipotezleri}

Araştırmamızda, yöneticilerin yeni yüzyılın gerektirdiği liderlik becerilerine sahip olma düzeyinin, yöneticilerin iş çevrelerinde yaşadığı stresi anlamlı bir şekilde etkilediği şeklinde teorik bir model geliştirilmiştir. Bunun yanında literatür taraması sonucunda yöneticilerin yaşadığı stres ile KOMB ve öz yeterlilik değişkenleri arasındaki ilişkiler de araştırılmaya değer görülmüştür.

$\mathrm{Bu}$ amaçla, yeni liderlik becerilerine sahip olma düzeyinin bağımsız değişken, yöneticilerin stres düzeyinin bağıml değişken ve bu değişkenler arasındaki ilişkiyi etkilediği varsayılan KOMB ve öz yeterlilik düzeyinin, moderatör (düzenleyici) değişken olarak yer aldığı bir araştırma modeli geliştirilmiştir. Şekil 1'de görülen modelde düz çizgiler değişkenler arasındaki doğrudan etkiyi temsil ederken kesikli çizgiler ise moderatör (düzenleyici) etkiyi temsil etmektedir.

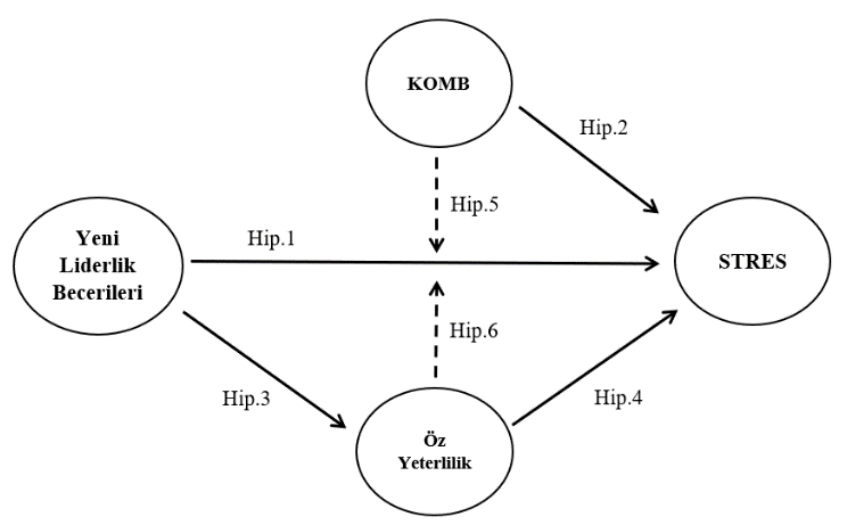

Şekil 1. Araştırma Modeli

$\mathrm{Bu}$ araştırmada modelin test edilmesinde yapısal eşitlik modeli kullanılmıştır. Şekil 1'de görülen araştırma modeline göre geliştirilen ana hipotezler aşağıda sıralanmıştır. Ayrıca bu araştırmada ana hipotezlerde yer alan değişkenlerin, alt boyutları arasındaki etki düzeyleri de karşılıklı olarak test edilmiştir.

Araştırma modeline göre geliştirilen ana hipotezler aşağıdaki gibidir (alt hipotezlere "Hipotez Testleri" başlığında değinilecektir):

Hip.1: Yeni liderlik becerilerine sahip olma düzeyinin, yönetici stresi üzerinde anlamlı bir etkisi vardır.

Hip.2: KOMB algısının, yönetici stresi üzerinde anlamlı bir etkisi vardır. 
Hip.3: Yeni liderlik becerilerine sahip olma düzeyinin, öz yeterlilik düzeyi üzerinde anlamlı etkisi vardır.

Hip.4: Öz yeterlilik düzeyinin, yönetici stresi üzerinde anlamlı bir etkisi vardır.

Hip.5: Yeni liderlik becerilerine sahip olma düzeyi ve KOMB algısı etkileşiminin yönetici stresi üzerinde anlamlı bir etkisi vardır.

Hip.6: Yeni liderlik becerilerine sahip olma düzeyi ve öz yeterlilik düzeyi etkileşiminin, yönetici stresi üzerinde anlamlı bir etkisi vardır.

\section{Bulgular}

\subsection{Demografik Verilere İlişkin Frekans Dağılımları}

Anket formları ile toplanan verilere göre demografik değişskenlere ilişkin frekans dağılımları Tablo 1'de gösterilmiştir.

Tablo 1. Demografik Değişkenlere İlişkin Frekanslar

\begin{tabular}{|c|c|c|c|}
\hline Değişken & Seçenekler & Frekans & $\begin{array}{l}\text { Yüzde } \\
(\%)\end{array}$ \\
\hline \multirow{3}{*}{ Yaş } & $26-45$ aras1 & 466 & 58,7 \\
\hline & $46-65$ aras 1 & 315 & 39,7 \\
\hline & 66 yaş ve üstü & 13 & 1,6 \\
\hline \multirow{3}{*}{$\begin{array}{l}\text { Öğrenim } \\
\text { Durumu }\end{array}$} & İlköğretim-Orta-Lise & 7 & 0,9 \\
\hline & Ön Lisans-Lisans & 440 & 55,4 \\
\hline & Lisansüstü & 347 & 43,7 \\
\hline \multirow{3}{*}{$\begin{array}{l}\text { Çalışılan } \\
\text { Pozisyon }\end{array}$} & $\begin{array}{l}\text { Yönetim/İcra Kurulu Bşk. } \\
\text { veya Üyesi veya CEO }\end{array}$ & 56 & 7,1 \\
\hline & G.Müdür / G.Müdür Yrd. & 157 & 19,8 \\
\hline & $\begin{array}{l}\text { Diğer (Koord., Direktör, } \\
\text { Depart./Birim Müdürü) }\end{array}$ & 581 & 73,1 \\
\hline Meslekte & $1-10$ y1l & 74 & 9,4 \\
\hline Çalışma & $11-20$ y1l & 341 & 42,9 \\
\hline Süresi & 21 yıl ve üzeri & 379 & 47,7 \\
\hline İşletmede & $1-10 \mathrm{yll}$ & 345 & 43,5 \\
\hline Çalışma & $11-20$ y1l & 293 & 36,9 \\
\hline Süresi & 21 yıl ve üzeri & 156 & 19,6 \\
\hline \multirow{15}{*}{ Sektör } & Ana Metallerin İmalatı & 74 & 9,3 \\
\hline & Deniz Taşıtları İmalatı & 2 & 0,4 \\
\hline & Elektrik Enerjisi Üretimi & 19 & 2,4 \\
\hline & $\begin{array}{l}\text { Elektrik ve Elektronik } \\
\text { Ürünlerin İmalatı }\end{array}$ & 50 & 6,3 \\
\hline & Gıda Ürünleri İmalatı & 118 & 14,9 \\
\hline & Giyim Ürünleri İmalatı & 8 & 1,0 \\
\hline & Kâğıt Ürünleri İmalatı & 15 & 1,9 \\
\hline & Kara Taşıtları İmalatı & 75 & 9,4 \\
\hline & Kimyasal Ürünlerin İmalatı & 56 & 7,1 \\
\hline & $\begin{array}{l}\text { Maden, Taş ve Toprak } \\
\text { Ürünleri İmalatı }\end{array}$ & 47 & 5,9 \\
\hline & $\begin{array}{l}\text { Makine, Aksam ve Metal } \\
\text { Eşya İmalatı }\end{array}$ & 59 & 7,4 \\
\hline & $\begin{array}{l}\text { Orman Ürünleri ve Mobilya } \\
\text { İmalatı }\end{array}$ & 26 & 3,3 \\
\hline & $\begin{array}{l}\text { Plastik ve Kauçuk Ürünlerin } \\
\text { İmalatı }\end{array}$ & 40 & 5,0 \\
\hline & Tekstil Ürünleri İmalatı & 60 & 7,6 \\
\hline & Diğer & 144 & 18,1 \\
\hline \multirow{3}{*}{$\begin{array}{l}\text { Çalışan } \\
\text { Sayısı }\end{array}$} & $0-49$ & 3 & 0,4 \\
\hline & $50-249$ & 47 & 5,9 \\
\hline & 250 ve üzeri & 744 & 93,7 \\
\hline TOPLAM & & 794 & 100 \\
\hline
\end{tabular}

Tablo 1 incelendiğinde, araştırmaya katılan yöneticilerin yüzde 58,7'lik bölümü 26-45 yaş aralığında bulunmaktadır. $\mathrm{Bu}$ da araştırmaya katılan şirketlerde genç yöneticilerin son derece yüksek bir orana sahip olduğunu göstermektedir. Bunun yanında araştırmaya katılan yöneticiler arasında Lisansüstü mezunlarının oranının da yüzde 43,7 olması da dikkat çekici bir sonuçtur. Ayrıca araştırmaya katılan yöneticilerin yüzde 73,1'lik kısmının Diğer (Koordinatör, Direktör, Departman veya Birim Müdürü) kategorisinde yer alan pozisyonlardan birinde çalıştığı görülmektedir. Şirket yönetim kurulu başkan ve üyelerine ulaşma zorluğu sebebiyle bu pozisyona ilişkin oran ise yüzde 7,1'de kalmıştır.

Tablo 1 incelendiğinde, araştırmaya katılan yöneticilerin toplamda yüzde 90,6'lık kısmının meslekte 10 yıldan fazla süredir çalıştığı görülmektedir. $\mathrm{Bu}$ durum araştırmaya katılan işletmelerde yönetici pozisyonunda bulunan kişilerin, çok büyük bir çoğunlukla mesleki deneyimi yüksek kişiler olduğunu göstermektedir. Bunun yanında araştırmaya katılan yöneticilerin toplamda yüzde 43,5'lik kısmının işletmede 10 yıldan az süredir çalıştığ görülmektedir. Buna karşılık kalan yüzde 56,5'lik kısım ise mevcut işletmede 10 yıldan fazla süredir çalışmaktadır. Bu durum araştırmaya katılan işletmelerde yönetici pozisyonunda bulunan kişilerde personel devir hızının düşük olduğu ve istikrarlı bir yönetici planlamasının yapıldığını göstermektedir. Son olarak araştırmaya katılan yöneticilerin çalıştıkları işletmelerin yüzde 93,7’lik kısmı büyük ölçekli işletme kategorisine giren, 250 ve üzeri çalışan sayısına sahiptir. Araştırmanın evreninin İSO500 listesine giren işletmeler olduğu düşünüldüğünde bu sonuç son derece normal kabul edilmektedir.

\subsection{Değişkenlere İlişkin Tanımlayıcı Analiz Bulguları}

Araştırmada kullanılan ölçeklere faktör analizi yapılmadan ve herhangi bir madde çıkarmadan önce, katılımcıların verdiği cevaplara ilişkin sonuçlar Tablo 2'de gösterilmiştir.

Tablo 2. Değişkenlere İlişkin Tanımlayıcı Analiz Sonuçları

\begin{tabular}{lcccc}
\hline Ölçek ve Alt Boyutlar & $\begin{array}{c}\text { Madde } \\
\text { Sayıs1 }\end{array}$ & N & Ort. & $\begin{array}{c}\text { Std. } \\
\text { Sapma }\end{array}$ \\
\hline YLBÖ & 10 & 397 & 2,05 & 0,59 \\
\hline ASÖ & 30 & 397 & 3,30 & 0,59 \\
Rahatsızlık & 4 & 397 & 3,45 & 0,84 \\
Aşırı Yük & 4 & 397 & 2,47 & 0,76 \\
Asabiyet & 2 & 397 & 3,45 & 0,92 \\
Keyifsizlik & 7 & 397 & 3,30 & 0,59 \\
Yorgunluk & 4 & 397 & 3,44 & 0,77 \\
Endişe & 5 & 397 & 3,26 & 0,77 \\
Gerginlik & 4 & 397 & 3,70 & 0,87 \\
\hline KOMBÖ & 20 & 397 & 3,16 & 0,49 \\
Karmaşıklık & 5 & 397 & 3,25 & 0,58 \\
Oynaklık & 5 & 397 & 2,50 & 0,65 \\
Muğlaklık & 5 & 397 & 3,49 & 0,67 \\
Belirsizlik & 5 & 397 & 3,38 & 0,67 \\
\hline GÖYÖ & 10 & 397 & 1,94 & 0,61 \\
\hline
\end{tabular}

Tablo 2 incelendiğinde, araştırmanın bağımsız değişkeni olan tek boyutlu Yeni Liderlik Becerileri değişkenine ilişkin ifadelerin ortalamasının 2,05 olduğu görülmektedir. Katılımcilara uygulanan anket formunda seçeneklerin " 1 Kesinlikle Katılıyorum” etiketi ile başladığı 
düşünüldüğünde, söz konusu değișkene ilişkin ifadelerin ortalaması son derece yüksek çıkmıştır. $\mathrm{Bu}$ sonuç yöneticiler arasında, yeni liderlik becerilerine sahip olma algısının yüksek oranda görüldügüünü göstermektedir.

Tablo 2'de yer alan verilere göre, araştırmanın bağımlı değişkeni olan yedi boyutlu stres değişkenine ilişkin ifadelerin ortalamasının 3,30 olduğu görülmektedir. $\mathrm{Bu}$ oran yöneticilerin stres düzeyinin ortalamanın biraz altında kaldığını göstermektedir. Algılanan stres ölçeğinin alt boyutlarına ilişkin ortalamalar incelendiğinde, Aşırı Yük alt boyutu dışındaki hemen hemen tüm alt boyutların yaklaşık oranlara sahip olduğu görülmektedir. Aşırı Yük alt boyutu ise $2,47^{\prime}$ lik ortalama ile yöneticilerin üzerinde fazla yük olduğunu ve bu yüzden stres yaşadıklarını göstermektedir.

Tablo 2'de, araştırmanın moderatör değişkenlerinden ilki olan KOMB değişkenine ilişkin ifadelerin ortalamasının 3,16 olduğu görülmektedir. $\mathrm{Bu}$ oran yöneticilerin $\mathrm{KOMB}$ algısının ortalamanın biraz altında kaldığını göstermektedir. KOMB ölçeğinin alt boyutlarına ilişkin ortalamalar incelendiğinde, Oynaklık alt boyutu dişındaki hemen hemen tüm alt boyutların yaklaşık oranlara sahip olduğu görülmektedir. Oynaklık alt boyutu ise 2,50'lik ortalama ile yöneticilerin iş çevrelerini karmaşık, muğlak ve belirsizden çok "oynak (değişken)" olarak tanımladıklarını göstermektedir.

Tablo 2 incelendiğinde, araştırmanın moderatör değişkenlerinden ikincisi olan ve tek boyuttan oluşan $\ddot{o z}$ yeterlilik değişkenine ilişkin ifadelerin ortalamasının 1,94 olduğu görülmektedir. $\mathrm{Bu}$ oran yöneticilerin öz yeterlilik inancının oldukça yüksek olduğunu göstermektedir. Dolayısıyla bu sonuca göre, yöneticiler mesleki anlamda kendilerini yüksek oranda yeterliliğe sahip olarak tanımlamaktadırlar.

\subsection{Güvenilirlik Analizi}

Günümüzde sosyal bilimler alanındaki araștırmaların neredeyse tamamında, ölçeğin iç tutarlılığının ölçüsü olarak güvenilirlik katsayısı olan alfa katsayısı kullanılmaktadır. Alfa katsayısı için yeterli denilebilecek eşik değer, üzerinde ittifakla 0,60 olarak kabul edilmektedir (Hair vd., 2010). Ancak Nunnally'ye (1978) göre, ölçüm modellerinin analizinde alfa katsayısından daha önemli olan kriter, bileşik güvenilirliğin (composite reliability) sağlanmasıdır. Nunally, bileşik güvenilirlik katsayısı için 0,70 veya 0,70'den yüksek değerleri önermiştir (Afthanorhan, 2013).

Araştırmamızda analiz edilen modele ilişkin ölçeklerin faktör analizlerinden önce ve açılayıcı/doğrulayıcı faktör analizleri sonrasında elde edilen alfa katsayısı ve bileşik güvenilirlik değerleri Tablo 3'de gösterilmiştir.

Tablo 3. Ölçeklerin Alfa ve Bileşik Güvenilirlik Değerleri

\begin{tabular}{lccc}
\hline Ölçek Ad1 & $\begin{array}{c}\text { Faktör } \\
\text { Analizi } \\
\text { Öncesi Alfa } \\
\text { Değeri }\end{array}$ & $\begin{array}{c}\text { Faktör } \\
\text { Analizleri } \\
\text { Sonrası Alfa } \\
\text { Değeri }\end{array}$ & $\begin{array}{c}\text { Faktör } \\
\text { Analizleri } \\
\text { Sonrası Bileşik } \\
\text { Güvenilirlik } \\
\text { Değeri }\end{array}$ \\
\hline YLBÖ & 0,851 & 0,823 & 0,883 \\
ASÖ & 0,884 & 0,780 & 0,851 \\
KOMBÖ & 0,750 & 0,703 & 0,805 \\
GÖYÖ & 0,907 & 0,912 & 0,928 \\
\hline
\end{tabular}

Tablo 3 incelendiğinde, elde edilen sonuçların Hair vd. (2010) ile Nunally (1978) tarafindan önerilen değerlerin çok üzerinde olduğu ve modelin hem içsel tutarlılığa hem de bütünsel güvenilirliğe sahip olduğu görülmüştür.

\subsection{Faktör Analizi}

Likert ölçek verileriyle yapılan araştırmalarda, faktör analizlerinden önce, özenle test edilmesi gereken en önemli varsayımlardan birisi normallik değerlendirmesidir (Şencan ve Fidan, 2020:641). Bu yüzden araştırmamızda verilerin normal dağılıp dağılmadığını tespit etmek için SPSS 21.0 programında hem Kolmogorov-Smirnov hem de ShapiroWilk testleri uygulanmış ve verilerin normal dağılım gösterdiği tespit edilmiştir.

Ardından araştırmada kullanılan Yeni Liderlik Becerileri, Stres, KOMB ve Öz Yeterlilik ölçekleri için, bir model geliştirmek ve faktörlerin yeterli olup olmadığını ölçmek için öncelikle açıklayıcı faktör analizi yapılmıştır. Ölçeklere uygulanan açıklayıcı faktör analizi sonucunda ortaya çıkan model ve faktör yapısının, veri seti açısından geçerliliğini doğrulamak için ise doğrulayıcı faktör analizleri yapılmıştır.

Açıklayıcı faktör analizinin yapılabilmesi için SPSS 21.0 programından yararlanılmıştır. Araştırmamızda açıklayıcı faktör analizi sonucunda değişkenlerin geçerli kabul edilecek faktör yükleri için alt sınır 0,40 olarak belirlenmiştir. Doğrulayıcı faktör analizinin yapılabilmesi için ise SmartPLS programından yararlanılmıştır. Doğrulayıcı faktör analizi sonucunda değişkenlerin geçerli kabul edilecek faktör yükleri için alt sınır Afthanorhan'ın (2013) önerdiği 0,50 olarak belirlenmiştir.

Her bir ölçek için yapılan açıklayıcı ve doğrulayıcı faktör analizlerinden elde edilen sonuçlar Tablo 4'de toplu olarak gösterilmiştir.

Tablo 4. Ölçeklere İlişkin Faktör Analizi Sonuçları

\begin{tabular}{|c|c|c|c|c|c|}
\hline \multirow[b]{2}{*}{$\begin{array}{l}\text { Ölçek } \\
\text { Ad1 }\end{array}$} & \multirow{2}{*}{$\begin{array}{c}\text { Faktör } \\
\text { Analizi } \\
\text { Öncesi } \\
\text { Faktör / } \\
\text { Madde } \\
\text { Sayılar1 } \\
\end{array}$} & \multicolumn{2}{|c|}{$\begin{array}{c}\text { Açıklayıcı } \\
\text { Faktör Analizi }\end{array}$} & \multicolumn{2}{|c|}{$\begin{array}{c}\text { Doğrulayıc1 } \\
\text { Faktör Analizi } \\
\end{array}$} \\
\hline & & $\begin{array}{c}\text { Faktör } \\
\text { Yük } \\
\text { Aralığ1 }\end{array}$ & $\begin{array}{l}\text { Faktör/ } \\
\text { Madde } \\
\text { Sayıs1 }\end{array}$ & $\begin{array}{c}\text { Faktör } \\
\text { Yük } \\
\text { Aralığ } 1\end{array}$ & $\begin{array}{c}\text { Faktör/ } \\
\text { Madde } \\
\text { Sayısı }\end{array}$ \\
\hline YLBÖ & $1 / 10$ & $\begin{array}{l}, 557- \\
, 870\end{array}$ & $2 / 10$ & $\begin{array}{l}, 583- \\
, 915\end{array}$ & $2 / 10$ \\
\hline ASÖ & $7 / 30$ & $\begin{array}{l}, 494- \\
, 827\end{array}$ & $5 / 24$ & $\begin{array}{l}.541- \\
, 856\end{array}$ & $4 / 21$ \\
\hline KOMBÖ & $5 / 20$ & $\begin{array}{l}, 491- \\
, 848\end{array}$ & $4 / 16$ & $\begin{array}{l}, 500- \\
, 831\end{array}$ & $3 / 13$ \\
\hline GÖYÖ & $1 / 10$ & $\begin{array}{l}539- \\
839 \\
\end{array}$ & $1 / 10$ & $\begin{array}{l}, 541- \\
, 826 \\
\end{array}$ & $1 / 9$ \\
\hline
\end{tabular}

Yapılan açıklayıcı faktör analizleri sonucunda, bazı ölçeklere ait bazı maddelerin faktör yüklerinin birden fazla faktör altında toplanması ve bu yükler arasında 0,10'dan daha az bir fark olması sebebiyle binişik madde kabul edilmesi sebebiyle analizden çıkarılmıştır. Doğrulayıcı faktör analizi sonucunda da faktör yük değerleri 0,50 değerinden düşük olan maddeler sirayla analiz dışı bırakılmıştır. 
SmartPLS programı ile yapılan doğrulayıcı faktör analizi sonucunda, araştırma modelinin son görünümü Şekil 2'de gösterilmiştir.

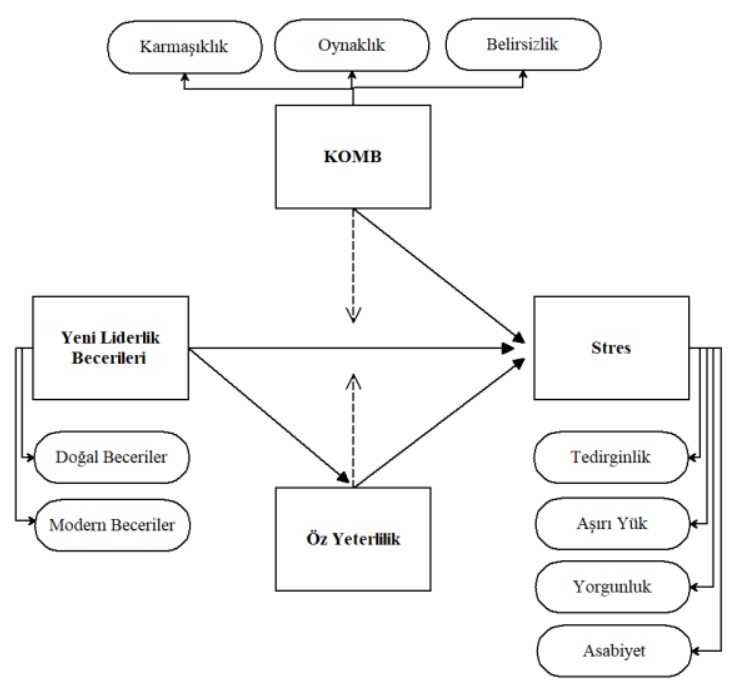

Şekil 2. DFA Sonrasında Araştırma Modelinin Görünümü

\subsection{Yapısal Eşitlik Modeli}

Doğrulayıcı faktör analizinden sonra araştırma hipotezlerine ilişkin analizlere geçilmiş ve bu analizler için Löhmoller'in kısmi en küçük kareler algoritmasından yararlanarak, "Kısmi En Küçük Kareler" yapısal eşitlik modellemesi yöntemi ile SmartPLS paket programı kullanılmıştır. Ancak bu yöntemde öncelikle modele ilişkin birleşme ve ayrışma geçerliliklerinin analiz edilmesi ve modelde çoklu doğrusal bağlantı probleminin bulunup bulunmadığı kontrol edilmelidir.

Bir modelin birleşme geçerliliğinin sağlanabilmesi için, Açıklanan Ortalama Varyans (AVE) değerlerinin Fornell ve Larcker'e (1981) göre 0,50'nin üzerinde olması gerekmektedir. Modelde yer alan alt boyutlara ilişkin analiz sonucunda tüm AVE değerleri 0,518 ile 0,808 arasında değerler almıştır. Ayrışma geçerliliği için yapılan analiz sonucunda ise gerekli iki kriter olan Fornell-Larcker ve HTMT kriterleri öngörülen sınırlar içinde değerler almıştır. Buna göre modelin hem birleşme geçerliliği hem de ayrışma geçerliliği koşulunu sağladığı görülmüştür. Ayrıca ölçek ifadelerine ait VIF değerlerinin ideal olan 1 değerine yakın sonuçlar vermesi araştırma modelinde çoklu doğrusal bağlantı probleminin de bulunmadığı göstermiştir.

\subsection{Hipotez Testleri}

Şekil 1'de yer alan kuramsal modeli oluşturan ilişkilerin test edilmesi amaciyla verilere, her bir değişkene ilişkin değerlerin en doğru şekilde hesaplanmasına izin veren kismi en küçük kareler (PLS) yol analizi uygulanmıştır.

Yapılan analiz sonucunda, değişkenler arasındaki ilişkiye ait yol katsayıları $(\beta), \mathrm{R}^{2}$ değerleri, standart sapmaları, t değerleri ve ilișkilerin $\% 5$ hata payı oranıyla anlamlı olup olmadığına ilişkin sonuçlar elde edilmiştir.

Hip.1 ana hipotezi doğrultusunda, yeni liderlik becerilerine sahip olma düzeyinin, yönetici stresi üzerindeki etkisini incelemek için yapılan analiz sonucunda aralarında anlamlı ilişki bulunan alt boyutlar Tablo 5'de gösterilmiştir.
(Tabloda yalnız aralarında anlamlı ilişki olan değişkenlere yer verilmiş, aralarında anlamlı ilişki bulunmayan alt boyutlar gösterilmemiştir.)

Tablo 5. Yeni Liderlik Becerileri ile Stres İlişkisi

\begin{tabular}{lccccc}
\hline İlişkiler & $\beta$ & $\mathrm{R}^{2}$ & $\mathrm{SS}$ & $\mathrm{T}$ & $\mathrm{P}$ \\
\hline $\begin{array}{l}\text { Modern Beceriler } \rightarrow \\
\text { Așırı Yük }\end{array}$ & 0,163 & 0,026 & 0,079 & 2,065 & $0,039^{*}$ \\
\hline $\begin{array}{l}\text { Doğal Beceriler } \rightarrow \\
\text { Așır1 Yük }\end{array}$ & 0,277 & 0,076 & 0,069 & 4,008 & $0,000^{* *}$ \\
\hline $\begin{array}{l}\text { Modern Beceriler } \rightarrow \\
\text { Asabivet }\end{array}$ & $-0,162$ & 0,026 & 0,070 & 2,324 & $0,020^{*}$ \\
\hline $\begin{array}{l}\text { Modern Beceriler } \rightarrow \\
\text { Yorgunluk }\end{array}$ & $-0,451$ & 0,203 & 0,051 & 8,885 & $0,000^{* *}$ \\
\hline $\begin{array}{l}\text { Doğal Beceriler } \rightarrow \\
\text { Yorgunluk }\end{array}$ & $-0,113$ & 0,012 & 0,051 & 2,202 & $0,028^{*}$ \\
\hline $\begin{array}{l}\text { Modern Beceriler } \rightarrow \\
\text { Tedirginlik }\end{array}$ & $-0,358$ & 0,128 & 0,066 & 5,419 & $0,000^{* *}$ \\
\hline$*$ p<0,05, **p<0,01 & & & & &
\end{tabular}

$\mathrm{Bu}$ sonuçlara göre; Hip.1 ana hipotezinin bazı alt hipotezlerinde kabul, bazılarında kısmen kabul, bazılarında ise red sonucu çıkması sebebiyle "Hip.1: Yeni liderlik becerilerine sahip olma algısının, yönetici stresi üzerinde anlamlı bir etkisi vardır." ana hipotezi, "kısmen kabul edilmiştir".

Hip.2 ana hipotezi doğrultusunda, KOMB algısının, yönetici stresi üzerindeki etkisini incelemek için yapılan analiz sonuçları Tablo 6'da gösterilmiştir. (Tabloda yalnız aralarında anlamlı ilişki olan değişkenlere yer verilmiş, aralarında anlamlı ilişki bulunmayan alt boyutlar gösterilmemiştir.)

Tablo 6. KOMB ile Stres İlişkisi

\begin{tabular}{lccccc}
\hline İlişkiler & $\beta$ & $\mathrm{R}^{2}$ & $\mathrm{SS}$ & $\mathrm{T}$ & $\mathrm{P}$ \\
\hline $\begin{array}{l}\text { Belirsizlik } \rightarrow \\
\text { Așır1 Yük }\end{array}$ & $-0,150$ & 0,022 & 0,061 & 2,445 & $0,015^{*}$ \\
\hline $\begin{array}{l}\text { Belirsizlik } \rightarrow \\
\text { Yorgunluk }\end{array}$ & $-0,137$ & 0,018 & 0,059 & 2,337 & $0,019^{*}$ \\
\hline $\begin{array}{l}\text { Belirsizlik } \rightarrow \\
\text { Tedirginlik }\end{array}$ & $-0,163$ & 0,026 & 0,064 & 2,553 & $0,011^{*}$ \\
\hline$* \mathrm{p}<0,05$ & & & & &
\end{tabular}

$\mathrm{Bu}$ sonuçlara göre; Hip.2 ana hipotezinin bazı alt hipotezlerinin kabul edilmesi bazılarının ise reddedilmesi sebebiyle, "Hip.2: KOMB algısının, yönetici stresi üzerinde anlaml bir etkisi vardır." ana hipotezi "k1smen kabul edilmiştir".

Hip.3 ana hipotezi doğrultusunda, yeni liderlik becerilerine sahip olma düzeyinin, öz yeterlilik düzeyi üzerindeki etkisini incelemek için yapılan analiz sonuçları Tablo 7'de gösterilmiştir. (Tabloda yalnız aralarında anlamlı ilişki olan değişkenlere yer verilmiş, aralarında anlamlı ilişki bulunmayan alt boyutlar gösterilmemiştir.)

Tablo 7. Yeni Liderlik Becerileri ile Öz Yeterlilik İlişkisi

\begin{tabular}{lccccc}
\hline İlişkiler & $\beta$ & $\mathrm{R}^{2}$ & $\mathrm{SS}$ & $\mathrm{T}$ & $\mathrm{P}$ \\
\hline $\begin{array}{l}\text { Modern Beceriler } \rightarrow \\
\text { Özyeterlilik }\end{array}$ & 0,137 & 0,018 & 0,055 & 2,492 & $0,013^{*}$ \\
\hline$* \mathrm{p}<0,05$ & & & & &
\end{tabular}

$\mathrm{Bu}$ sonuçlara göre; Hip.3 ana hipotezini ilgilendiren bir alt boyutun anlamlı diğer alt boyutun ise anlamsız ilişki göstermesi sebebiyle "Hip.3: Yeni liderlik becerilerine 
sahip olma düzeyinin, öz yeterlilik düzeyi üzerinde anlamlı bir etkisi vardır." ana hipotezi "kısmen kabul edilmiştir".

Hip.4 ana hipotezi doğrultusunda, öz yeterlilik düzeyinin, yönetici stresi üzerindeki etkisini incelemek için yapılan analiz sonuçları Tablo 8'de gösterilmiştir. (Tabloda yalnız aralarında anlamlı ilişki olan değişkenlere yer verilmiş, aralarında anlamlı ilişki bulunmayan alt boyutlar gösterilmemiştir.)

Tablo 8. Öz Yeterlilik ile Stres İlişkisi

\begin{tabular}{lccccc}
\hline İlişkiler & $\beta$ & $\mathrm{R}^{2}$ & $\mathrm{SS}$ & $\mathrm{T}$ & $\mathrm{P}$ \\
\hline $\begin{array}{l}\text { Özyeterlilik } \rightarrow \\
\text { Yorgunluk }\end{array}$ & $-0,124$ & 0,015 & 0,063 & 1,979 & $0,048^{*}$ \\
\hline$* \mathrm{p}<0,05$ & & & & &
\end{tabular}

$\mathrm{Bu}$ sonuçlara göre; Hip.4 ana hipotezinin bazı alt hipotezlerinin kabul edilmesi bazılarının ise reddedilmesi sebebiyle "Hip.4: Öz yeterlilik düzeyinin, yönetici stresi üzerinde anlamlı bir etkisi vardır." ana hipotezi "kısmen kabul edilmiştir".

Hip.5 ana hipotezi doğrultusunda, yeni liderlik becerilerine sahip olma düzeyi ve KOMB algısı etkileşiminin, yönetici stresi üzerindeki etkisini incelemek için yapılan analiz sonucunda, değişkenler arasında hiçbir anlamlı ilişki görülmemiştir. Sonuç olarak Hip.5 ana hipotezinin tüm alt hipotezlerinin reddedilmesi sebebiyle "Hip.5: Yeni liderlik becerilerine sahip olma düzeyi ve KOMB algisı etkileşiminin yönetici stresi üzerinde anlaml bir etkisi vardır." ana hipotezi "reddedilmiştir".

Hip.6 ana hipotezi doğrultusunda, yeni liderlik becerilerine sahip olma düzeyi ve öz yeterlilik düzeyi etkileşiminin, yönetici stresi üzerindeki etkisini incelemek için yapılan analiz sonucunda, değişkenler arasında hiçbir anlamlı ilişki görülmemiştir. Sonuç olarak Hip.6 ana hipotezinin tüm alt hipotezlerinin reddedilmesi sebebiyle "Hip.6: Yeni liderlik becerilerine sahip olma düzeyi ve öz yeterlilik düzeyi etkileşiminin, yönetici stresi üzerinde anlaml bir etkisi vardır." ana hipotezi "reddedilmiştir".

Yapılan hipotez testleri sonucunda, ana hipotezlere ait sonuçlar Tablo 9'da toplu olarak gösterilmiştir.

Tablo 9. Ana Hipotezlere İlişkin Analiz Sonuçları

\begin{tabular}{|c|c|}
\hline HIPOTEZLER & SONUÇ \\
\hline $\begin{array}{l}\text { Hip.1: Yeni liderlik becerilerine sahip olma } \\
\text { düzeyinin, yönetici stresi üzerinde anlamlı bir etkisi } \\
\text { vardır. }\end{array}$ & $\begin{array}{c}\text { Kismen } \\
\text { Kabul }\end{array}$ \\
\hline $\begin{array}{l}\text { Hip.2: KOMB algısının, yönetici stresi üzerinde } \\
\text { anlamlı bir etkisi vardır. }\end{array}$ & $\begin{array}{c}\text { Kismen } \\
\text { Kabul }\end{array}$ \\
\hline $\begin{array}{l}\text { Hip.3: Yeni liderlik becerilerine sahip olma } \\
\text { düzeyinin, öz yeterlilik düzeyi üzerinde anlamlı bir } \\
\text { etkisi vardır }\end{array}$ & $\begin{array}{c}\text { Kismen } \\
\text { Kabul }\end{array}$ \\
\hline $\begin{array}{l}\text { Hip.4: Öz yeterlilik düzeyinin, yönetici stresi } \\
\text { üzerinde anlamlı bir etkisi vardır. }\end{array}$ & $\begin{array}{c}\text { Kismen } \\
\text { Kabul }\end{array}$ \\
\hline $\begin{array}{l}\text { Hip.5: Yeni liderlik becerilerine sahip olma düzeyi } \\
\text { ve KOMB algıs etkileşiminin yönetici stresi } \\
\text { üzerinde anlamlı bir etkisi vardır. }\end{array}$ & Red \\
\hline $\begin{array}{l}\text { Hip.6: Yeni liderlik becerilerine sahip olma düzeyi } \\
\text { ve öz yeterlilik düzeyi etkileşiminin, yönetici stresi } \\
\text { üzerinde anlamlı bir etkisi vardır. }\end{array}$ & Red \\
\hline
\end{tabular}

Yapısal eşitlik modelinin test edilmesinden sonra, değişkenler arasındaki ilişkilerin genel görünümü ise Şekil 3'de gösterilmiştir.

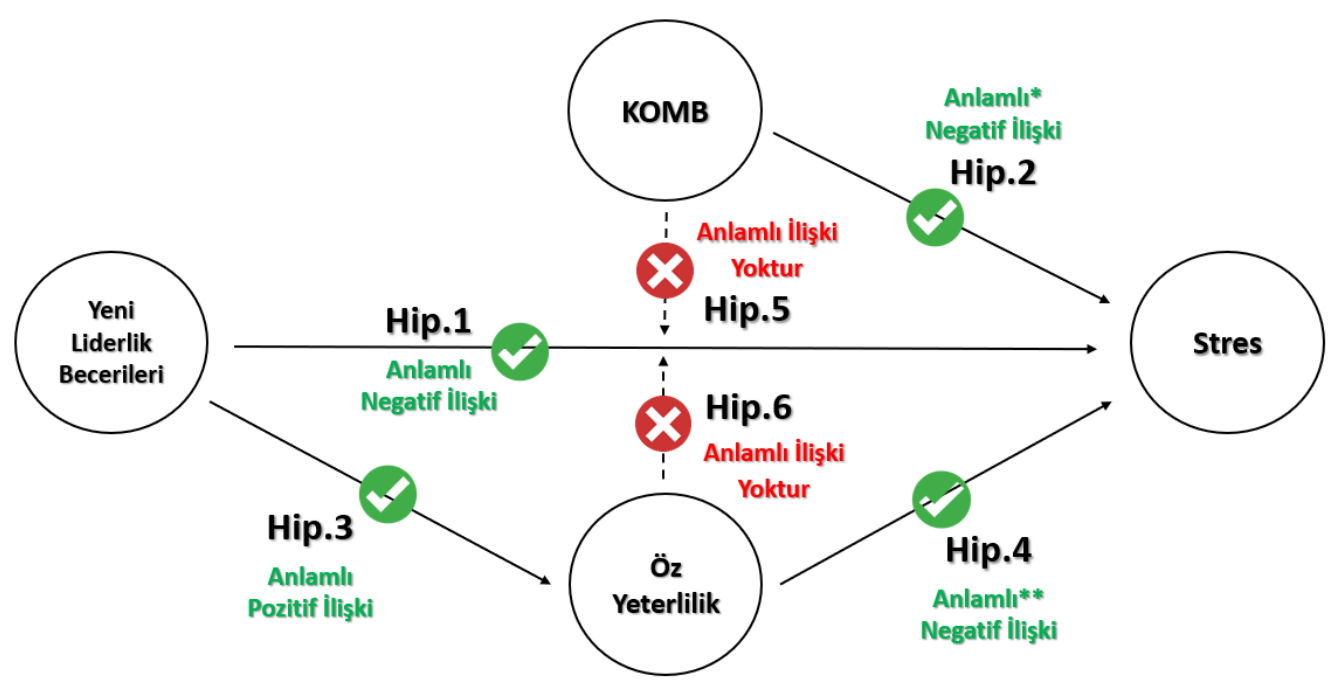

* KOMB ölçeğinin sadece "Belirsizlik" boyutu ile Stres ölçeğinin "Aşırı Yük, Yorgunluk ve Tedirginlik" boyutları arasinda anlamlı ilişki vardır.

** Öz Yeterlilik ölçeği ile Stres ölçeğinin sadece "Yorgunluk" alt boyutu arasında anlamlı bir ilişki vardır.

Şekil 3. Değişkenler Arası İlişkilerin Araştırma Modeli Üzerinde Genel Görünümü

\section{Sonuç}

Günümüzün en önemli bireysel, örgütsel ve toplumsal sorunlarından birisi strestir. Yapılan araştırmalara göre en sık karşılaşılan stres türü ise, mesleki konularla ilgili ve iş kaynaklı strestir. Bu araştırmada, yöneticilerin Johansen tarafindan geliştirilen yeni liderlik becerilerine sahip olma düzeyinin yaşadıkları stresi negatif yönlü anlamlı bir şekilde etkilediği görülmüştür. Bir başka ifadeyle, yöneticilerin yeni liderlik becerilerine sahip olma düzeyi arttıkça, yaşadıkları stres azalmaktadır. Bu sonuç Githens (2015) ve Webb (2016) gibi yazarların, KOMB 
koşullarında çalışmanın yöneticilerde yoğun bir strese yol açtığı ve bu becerilerin yöneticileri KOMB koşullarında başarılı ve dirençli kıldığı şeklindeki görüşünü destekler niteliktedir.

Araştırmada ayrıca, yöneticilerin KOMB algısı arttıkça yaşadıkları stresin azaldığı sonucuna ulaşılmıştır. Yöneticilerin karmaşık, oynak, muğlak ve belirsiz ortamlarda stres düzeyinin yükselmesi beklenirken, azalıyor olması, ilgili literatüre (Webb, 2016; Githens, 2015) bir tezat oluşturmaktadır.

Araştırma elde edilen bir diğer sonuç ise yöneticilerin yeni liderlik becerilerine sahip olma düzeyi arttıkça, öz yeterlilik inancının da artmasıdır. Yöneticilerde öz yeterlilik düzeyinin, yaşadıkları stres düzeyi ile ilişkili olup olmadığı incelendiğinde ise öz yeterliliği yüksek olan yöneticilerin daha az stres yaşadığı görülmüştür (Bandura, 1994:71-81; Kurbanoğlu, 2004:139; Baltac1, 2008:35).

Araştırmada son olarak, yöneticilerde yeni liderlik becerilerine sahip olma düzeyi ile yöneticilerin KOMB algısı ve öz yeterlilik etkileşiminin, yöneticilerin yaşadıkları stres düzeyi üzerinde anlamlı bir etkisi olup olmadığı araştırılmıştır. Buna göre, yeni liderlik becerilerine sahip olma düzeyi yöneticilerin stres düzeyini anlamlı bir şekilde etkilerken, bu ilişkiye KOMB algısı ya da öz yeterlilik düzeyi moderatör (düzenleyici) değişken olarak dahil edildiğinde ve yeni liderlik becerileri ile etkileşime girdiğinde -ki bu etkileşim sonucu oluşan yeni değişkene etkileşim değişkeni de denilmektedir- stres üzerinde anlamlı bir etki ortaya çıkarmamıştır. Bir başka ifadeyle KOMB algısı ve öz yeterlilik, yeni liderlik becerilerine sahip olma düzeyinin stres düzeyi üzerindeki anlamlı etkisini ortadan kaldırmıştır.

Özetleyecek olursak; bu araştırmadan elde edilen en önemli sonuç, çağımızın ve içinde yaşadığımı KOMB (karmaşıklık, oynaklık, muğlaklık, belirsizlik) dünyasının gerektirdiği 21. yüzyılın yeni liderlik becerilerine sahip olan yöneticilerin, yaptıkları işe bağlı stresten daha az etkilendiğidir. Yine araştırma sonuçlarına göre bu becerilere sahip olmak yöneticilerin öz yeterlilik inançlarını da artırmaktadır.

Tüm bu sonuçlar 1şığında işletmelere sunulabilecek başlıca öneriler aşağıda sıralanmıştır:

1. Yöneticilerde işe bağlı stresin azaltılabilmesi için, mevcut yöneticilerin yeni liderlik becerilerine sahip olma düzeyinin arttırılması gerekmektedir. Bunu sağlamak için yönetici geliştirme programları düzenlenebilir ya da mevcut programlara bu araştırmada ele alınan yeni liderlik becerilerinin entegre edilebilir.

2. Potansiyel yöneticileri ve yönetici adaylarını yetiştirme sürecinde de yeni liderlik becerilerinin kazandırılmasına yönelik eğitimler düzenlenmelidir.

3. Araştırma sonuçlarına göre yöneticilerin KOMB'un oynaklık dışındaki bileşenlerini (karmaşıklık, belirsizlik, muğlaklık) hissetme ve algılama oran1 düşüktür. $\mathrm{Bu}$ konuda yöneticiler nezdinde farkındalık oluşturulmal1, konu ile ilgili zirve, kongre ya da sempozyumlar organize edilmeli ya da mevcut olanlara yönetici ve yönetici adaylarının katılımı sağlanmalıdır.
4. Yöneticilerde öz yeterlilik inancının yüksek olmasının stres düzeyini azaltması sebebiyle, yöneticilerin öz yeterlilik inancını artırmak için çaba harcanmalıdır.

5. Yöneticilerin yaşadıkları ve gelecekte yaşaması muhtemel stresli koşullar ile başa çıkmayı öğrenmeleri için stres yönetimi eğitimi almaları sağlanmalıdır.

6. Son olarak, araştırma kısıtları da dikkate alınmak suretiyle araştırmanın, ilgili kuruluşlarda örneklem olarak seçilen yöneticiler dışındaki çalışanlar üzerinde de yapılması, daha sağlıklı bir karşılaştırma imkânı verecektir. Dolayısıyla bu konuya ilgi duyan araştırmacılara, araştırmanın farklı firmalar ve yöneticilerin katılımıyla, farklı zamanlarda tekrar yapılması önerilmektedir. Ayrıca yöneticilerden elde edilecek bilgilerin daha sağlıklı olmasını ve gerçek durumu yansıtmasını sağlamak için, veri toplama sürecinin, yüzyüze anket yöntemi ile gerçekleştirilmesi de önerilmektedir.

\section{Kaynakça}

Afthanorhan, W. (2013). A Comparison of Partial Least Square Structural Equation Modeling (PLS-SEM) and Covariance Based Structural Equation Modeling (CB-SEM) for Confirmatory Factor Analysis. International Journal of Engineering Science and Innovative Technology, 2(5), 198-205.

Akgündüz, Y. (2012). Konaklama Işsletmelerinde Otantik Liderlik ve Öz Yeterlilik Arasındaki İlişkinin Analizi. Doktora Tezi. İzmir: Dokuz Eylül Üniversitesi.

Anonim (2011). Next Practices/Technologies Tools and Methodologies: Strategic Foresights in VUCA World. (Erişim: 13.01.2017), https://areete.wordpress.com/2011 /12/20/vuca-andleadership-skills-for-future/

Automatic Data Processing (2016). Dealing with a VUCA World: HR's Investment Opportunity. (Erişim: 24.03.2017),

http://www.adp.com.hk/assets/vfs/Family-33/HongKong/White-Paper-Download/adp-vuca-report final.pdf

Aypay, A. (2010). Genel Öz Yeterlik Ölçeği’nin (GÖYÖ) Türkçe'ye Uyarlama Çalışması. Inönü Üniversitesi Eğitim Fakültesi Dergisi, 11(2), 113-131.

Baltacı, H. (2008). Ilköğretim Okullarında Görev Yapan Yöneticilerin Bilgisayar Tutumlarl ile ÖzYeterlilikleri Arasindaki Ilişkinin Incelenmesi. Yüksek Lisans Tezi. İstanbul: Yeditepe Üniversitesi.

Bandura, A. (1994). Self-efficacy. V. Ramachaudran (Ed.) Encyclopedia of Human Behavior (s. 71-81). New York: Academic Press.

Bandura, A. (1982). Self-efficacy Mechanism in Human Agency. American Psychologist, 37(2), 122-147.

Battey, J. (2012). The Future is Already Here. (Erişim: 05.07.2019), http://miramarfarms.com/the-future-isalready-here/

Bennis, W., \& Nanus, B. (1985). Leaders: The Strategies for Taking Charge. New York: Harper \& Row. 
Brittain, B. (2012). Leadership Perfected: Leading From The Whole You. (Erişim: 11.01.2017), http://iveybusinessjournal.com/publication/leadershi p-perfectedleading-from-the-whole-you

Casey, G. W. (2014). Leading in a VUCA World. Fortune Journal, 169(5), 75.

Collins, J., \& Hansen, M. (2011). Great By Choice: Uncertainty, Chaos, and Luck -Why Some Thrive Despite Them All. New York: NY: Harper Collins.

Convay, J., \& Lance, C. (2010). What Reviewers Should Expect From Authors Regarding Common Method Bias in Organizational Research. Journal of Business and Psychology, 25, 325-334.

Cooke, A. (2013). How to Manage Volatility, Uncertainty, Complexity and Ambiguity - Part 1. (Erişim: 07.04.2017), https://growthandprofit.me/category/vuca/

Erdoğan, İ. (1999). İşletme Yönetiminde Kişiliğe Bağlı Çatışma, Stres ve Çözüm Yollart. Ankara: MESS Yayınlar1.

Eren, E. (2004). Örgütsel Davranış ve Yönetim Psikolojisi. İstanbul: Beta Yayınları.

Fornell, C., \& Larcker, D. (1981). Evaluating Structural Equation Models with Unobservable Variables and Measurement Error. Journal of Marketing Research, (48), 39-50.

Githens, G. (2015). Volatility, Uncertainty, Complexity and Ambiguity (VUCA). (Erişim: 13.03.2020), https://leadingstrategicinitiatives.com/2015/02/27/vo latility-uncertainty-complexity-ambiguity-vuca/

Guterman, M., \& King, D. (2014). Working La Vida VUCA. (Erişim: http://www.meaningfulcareers. com/working-lavida-vuca/

Gürbüz, S., \& Şahin, F. (2017). Sosyal Bilimlerde Araştırma Yöntemleri. Ankara: Seçkin Yayıncılık.

Hair, J., Black, W., Babin, B., \& Anderson R. E. (2010). Multivariate Data Analysis. New Jersey: Prentice Hall.

Hazır Bıkmaz, F. (2004). Sinıf Öğretmenlerinin Fen Ögretiminde Öz Yeterlilik İnancı Ölçeğinin Geçerlik ve Güvenirlik Çalışmast. (Erişim: 26.03.2020), http://dhgm.meb.gov.tr/yayimlar/dergiler/Milli_Egiti m_Dergisi/161/bikmaz.htm

Johansen, B. (2012). Leaders Make The Future: Ten New Leadership Skills for an Uncertain World. San Francisco: CA: Berrett-Koehler.

Johansen, B. (2010). Speed in a VUCA World: How Leaders of the Future Will Execute Strategy. (Erişim: 11.04.2017), http://www.forevueinternational.com/Content/sites/forevue/pages/1481/3_2_Speed_in_a_VU CA_World_Johansen.PDF

Kurbanoğlu, S. (2004). Özyeterlik İnançları ve Bilgi Profesyonelleri İçin Önemi. Bilgi Dünyası, 5(2), 137-152.
Lazarus, R. (1993). From Psychological Stress to the Emotions: A History of Changing Outlooks. Annual Review of Psychology, 44, 1-21.

Levenstein, S., Prantera, C., Varvo, V., Scribano, M., Berto, E., Luzi, C., \& Andreoli, A. (1993). Development of the Perceived Stress Questionnaire: A New Tool for Psychosomatic Research. Journal of Psychosomatic Research, 37(1), 19-32.

Lindell, M., \& Whitney, D. (2001). Accounting for Common Method Variance in Cross-Sectional Research Designs. Journal of Applied Psychology, 86, 114-121.

Michel, J. (2016). The What, How and Now of Effectively Leading Change. (Erişim: 11.01.2017), http://www. brandquarterly.com/what-how-now-ofeffectivelylead ing-change

Nunnally, J. (1978). Psychometric Theory. New York: McGraw-Hill.

Örnek, A. Ş., \& Aydın, Ş. (2008). Kriz ve Stres Yönetimi. Ankara: Detay Yayıncılik.

Özyılmaz, A., \& Eser, S. (2013). Ortak Metod Varyansı Nedir? Nasil Kontrol Edilebilir?. Ankara: Nobel Akademik Yayıncılık.

Paşa, M. (2007). Stresin Bireysel Performans Üzerindeki Etkileri ve Bir Uygulama. Doktora Tezi. Bursa: Uludağ Üniversitesi.

Podsakoff, P., MacKenzie, S., Lee, J., \& Podsakoff, N. (2003). Common Method Biases in Behavioral Research: A Critical Review of the Literature and Recommended Remedies. Journal of Applied Psychology, 88, 879-903.

Podsakoff, P., MacKenzie, S., \& Podsakoff, N. (2012). Sources of Method Bias in Social Science Research and Recommendations on How to Control It. Annual Review of Psychology, 63, 539-569.

Prensky, M. (2014). Variability, Uncertainty, Complexity and Ambiguity (VUCA). (Erişim: 13.01.2017), http://blogs.edweek.org/edweek/provocative-edtechthin king/2014/09/Post_0006variability_uncertainty_comp lexity_ambiguity_vuca.html

Richardson, H., Simmering, M., \& Sturman, M. (2009). A Tale of Three Perspectives: Examining Post Hoc Statistical Techniques for Detection and Correction of Common Method Variance. Organizational Research Methods, 12, 762-800.

Schwarzer, R., \& Jerusalem, M. (1995). Generalized selfefficacy scale. J. Weinman, S. Wright, \& $\mathrm{M}$. Johnston (Ed.), Measures in Health Psychology: A User's Portfolio, Causal and Control Beliefs. Winsdor: NFER-Nelson.

Shaffer, L. S., \& Zalewski, J. M. (2011). Career Advising in a VUCA Environment. The Journal of the National Academic Advising Association, 31(1), 1320. 
Sullivan, J. (2012). VUCA: The New Normal for Talent Management and Workforce Planning. (Erişim: 24.03.2020), https://www.eremedia.com/ere/vucathe-new-normal-for-talent-management-andworkforce-planning/

Şencan, H., \& Fidan, Y. (2020). Likert Verilerinin Kullanıldığı Keşfedici Faktör Analizlerinde Normallik Varsayımı ve Faktör Çıkarma Üzerindeki Etkisinin SPSS, FACTOR ve PRELIS Yazılımlarıyla Sinanması. Business \& Management Studies: an International Journal, 8(1): 640-687.

Tutar, H. (2000). Kriz ve Stres Ortamında Yönetim. İstanbul: Hayat Yayınları.

Webb, L. (2016). Living in a VUCA World. (Erişim: 13.03.2020), https://www.trainingjournal.com/articles/ magazine/january-2016

Williams, L., Hartman, N., \& Cavazotte, F. (2010). Method Variance and Marker Variables: A Review and Comprehensive CFA Marker Technique. Organizational Research Methods, 13, 477-514.

Yiğitbaş, Ç., \& Yetkin, A. (2003). Sağlık Yüksekokulu Öğrencilerinin Öz-Etkililik-Yeterlilik Düzeyinin Değerlendirilmesi. Cumhuriyet Üniversitesi Hemşirelik Yüksekokulu Dergisi, 7(1), 6-13.

Yurdasever, E. (2019). Yöneticilerde Yeni Liderlik Becerileri ile Stres Ilişsisi: KOMB (VUCA) ve $\ddot{O}_{z}$ Yeterlilik Etkileşimi. Doktora Tezi. Karabük: Karabük Üniversitesi. 
EK -1 (Etik Kurul İzni)

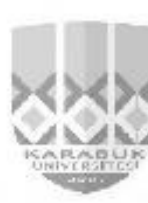

T.C.

KARABÜK ÜNIVERSITESI

SOSYAL ve BEȘERI BILLIMLER ARAŞTIRMALARI ETIK KURULU

KARARLARI

TOPLANTI TARIHI: 31.05 .2018

TOPLANTI NO : 2018/07

Karabük Üniversitesi Sosyal ve Beşeri Bilimler Araştırmaları Etik Kurulu toplanmış ve aşağıdaki kararı almıștı.

\section{Karar 3:}

22.05.2018 tarih ve 13 sayılı Prof. Dr. Yahya FíDAN' in dilekçesi ve eki görüşüldü.

Öniversitemiz Işletme Anabilim dalı Yükssek lisans öğrencisi Engin YURDASEVER' in hazırlamakta olduğu "VUCA Dänyasında Yönetim ve Yeni Liderlik Becerilerinin Algılanan Ônemi" konulu çałışmasın uygulamak üzere ekte sunulan anket çalışmasının etik kurallara uygunluğu oy birliği ile kabul edilmiştir.

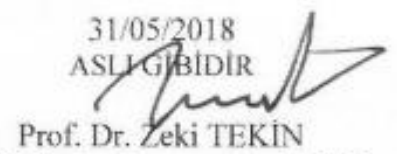

Sosyal ve Beșeri Bilimler Araștırmaları Etik Kurul Başkanı

Kalp ve damar hastaliklanndan korunmak için sağhkla beslenmeve dxen gbsteriniz.

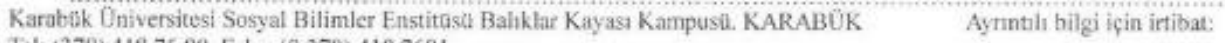

Tel: (370) 4187680 Faks: (0) 370$) 4187681$

e-postasbe(a)karabuk.edu.tr 